\title{
Multi-decadal variations in glacier flow velocity and the influencing factors of Urumqi Glacier No. 1 in Tianshan Mountains, Northwest China
}

\author{
WANG Puyu $^{1 *}$, LI Zhongqin ${ }^{1,2}$, XU Chunhai $^{1}$, XING Wucheng $^{2}$, ZHOU Ping $^{1}$, ZHANG Hui ${ }^{1}$ \\ ${ }^{1}$ State Key Laboratory of Cryosphere Science/Tianshan Glaciological Station, Northwest Institute of Eco-Environment and \\ Resources, Chinese Academy of Sciences, Lanzhou 730000, China; \\ ${ }^{2}$ College of Geography and Environment Science, Northwest Normal University, Lanzhou 730070, China
}

\begin{abstract}
Urumqi Glacier No. 1 is a representative glacier in the inland areas of Central Asia and is the only Chinese reference glacier in the World Glacier Monitoring Service. In this study, we explored multi-decadal variations in the flow velocity of the glacier and the influencing factors based on continuous field observations and path coefficient analysis. Results show that the glacier flow velocity decreased from $5.5 \mathrm{~m} / \mathrm{a}$ in $1980 / 1981$ to $3.3 \mathrm{~m} / \mathrm{a}$ in $2010 / 2011$. The annual variation in the direction of glacier flow velocity in the western branch and eastern branch was less than $1^{\circ}-3^{\circ}$, and the change of glacier flow velocity in the western branch was more dramatic than that in the eastern branch. Glacier flow velocity was influenced by glacier morphology (including glacier area, glacier length, and ice thickness), glacier mass balance and local climate conditions (air temperature and precipitation), the glacier morphology being the leading factor. The long-term flow velocity data set of Urumqi Glacier No. 1 contributes to a better understanding of glacier dynamics within the context of climatic warming.
\end{abstract}

Keywords: glacier flow velocity; glacier change; path coefficient analysis; Urumqi Glacier No. 1; Chinese Tianshan Mountains

Citation: WANG Puyu, LI Zhongqin, XU Chunhai, XING Wucheng, ZHOU Ping, ZHANG Hui. 2017. Multi-decadal variations in glacier flow velocity and the influencing factors of Urumqi Glacier No. 1 in Tianshan Mountains, Northwest China. Journal of Arid Land, 9(6): 900-910. https://doi.org/10.1007/s40333-017-0067-6

\section{Introduction}

Glaciers and ice sheets are sensitive to climate change and preserve abundant water resources (Oerlemans and Fortuin, 1992; Haeberli et al., 2002; Oerlemans, 2005; Meier et al., 2007; Li et al., 2012; IPCC, 2013). Global warming has driven a significant global reduction in the mass balance of most glaciers during the second half of the $20^{\text {th }}$ century, resulting in a general retreating trend. This retreat was intensified at the end of the last century (Dyurgerov and Meier, 2000; Khromova et al., 2003; Paul et al., 2004; Barry, 2006; Li et al., 2010; Wang et al., 2013). Glacier flow velocity refers to the rate of downhill motion under the influence of gravity, and this motion process includes sliding on the glacier bedrock and the internal deformation of the glacier (Singh and Singh, 2001). Flow velocity is a basic parameter of glacier and is one of the main characters that differentiate glaciers from other natural ice bodies (Huang and Sun, 1982; Kääb, 2005). Glacier flow velocity varies at spatial and temporal scales. Monitoring of glacier flow velocity is a key to understanding the dynamics of glaciers (Zhou et al., 2009; Cuffey and Paterson, 2010).

*Corresponding author: WANG Puyu (E-mail: wangpuyu@lzb.ac.cn)

Received 2017-03-04; revised 2017-07-18; accepted 2017-08-10

(C) Xinjiang Institute of Ecology and Geography, Chinese Academy of Sciences, Science Press and Springer-Verlag GmbH Germany 2017 
Glacier flow velocity is a main factor controlling the glacier dynamics and depends on the dimensional parameters and physical properties of the glacier, such as ice thickness, surface and bed slopes, and ice temperature (Hodge, 1974; Mair et al., 2001). Under global warming, glacier loss can lead to changes in these parameters (or properties) and may then result in flow velocity change.

In previous studies, various methods have been adopted to study glacier flow velocity, including field measurements (e.g., Manson et al., 2000; Hubbard and Glasser, 2005; Sugiyama et al., 2013) and remote sensing technologies (Strozzi et al., 2002; Nishimura et al., 2013; Schubert et al., 2013). Generally speaking, repeated field measurements of ablation stakes are the first and best choice for studying glacier flow velocity with high spatial and temporal accuracy (e.g., Manson et al., 2000; Hubbard and Glasser, 2005; Sugiyama et al., 2013), although repeated field measurements are only applicable to few easy-to-access glaciers and are quite labor and time consuming.

Urumqi Glacier No. 1 is the only Chinese reference glacier in the World Glacier Monitoring Service (WGMS) and regarded as a representative for glaciers in the inland areas of Central Asia (Zemp et al., 2009). Flow velocity of Urumqi Glacier No. 1 has traditionally been measured by placing networks of stakes in the glacier surface and surveying their displacement at regular time intervals. Glacier flow velocity measurement was once taken in September 1959 and in August-September 1973. Since 1980, glacier flow velocity was systematically and persistently surveyed every year by various instruments, e.g., theodolite, total station and RTK-GPS (real time kinematic-global positioning system) (Tianshan Glaciological Station, 2011). In recent years, field surveys of stakes become easier and more accurate via the introduction of global positioning systems (GPS) (Zhou et al., 2009; Wang et al., 2014a). The monthly observation-based seasonal changes of glacier flow velocity of Urumqi Glacier No. 1 in 2006-2008 were previously reported (Zhou et al., 2009). However, long-term variations of glacier flow velocity have not yet been reported.

The aims of this study are: (1) to analyze the spatial distributions of glacier flow velocity of Urumqi Glacier No. 1 in 1980/1981, 1990/1991, 2000/2001, and 2010/2011 with the time interval of 10 years, and (2) to present the long-term changes in glacier flow velocity from 1981 to 2011. The influencing factors are also discussed.

\section{Study area}

The Tianshan Mountains range is one of the major mountian ranges in Central Asia, with peaks rising from $\sim 4000$ to $\sim 6000 \mathrm{~m}$ a.s.l. Urumqi Glacier No. $1\left(43^{\circ} 06^{\prime} 30^{\prime \prime} \mathrm{N}, 86^{\circ} 48^{\prime} 30^{\prime \prime} \mathrm{E}\right.$; Fig. 1), a continental valley glacier, is located at the headwaters of Urumqi River in the Tianshan Mountains, Northwest China. The glacier covers northeast-facing slopes on the flanks of the Tianger Peak II with an altitude of $4484 \mathrm{~m}$ a.s.l. Both glacier accumulation and ablation occur in summer. The westerlies jet steam prevails across the area throughout the year.

The area of Urumqi Glacier No.1 was reduced by $0.3 \mathrm{~km}^{2}(15.7 \%)$ during 1962-2009. The terminus retreated with an average rate of $4.5 \mathrm{~m} / \mathrm{a}$ from 1959 to 1993 , and subsequently the glacier was separated into two independent branches (i.e., eastern branch and western branch) in 1993. During 1994-2008, the terminus retreat rate was 6.0 and $3.5 \mathrm{~m} / \mathrm{a}$ for the eastern branch and western branch, respectively ( $\mathrm{Li}$ et al., 2011; Xu et al., 2011). According to the measurement results of B-1 radar-sounding system designed by Lanzhou Institute of Glaciology and Geocryology, Chinese Academy of Sciences (current name: Northwest Institute of Eco-Environment and Resources, Chinese Academy of Sciences) and ground penetrating radar, the average ice thickness was 55.1, 51.5, and $48.4 \mathrm{~m}$ for 1981, 2001, and 2006, respectively, and the bedrock elevation decreased towards the glacier terminus, exhibiting a U-shaped subglacial valley (Wang et al., 2014b). Li et al. (2012) developed an extended "perfect-plasticity" method to estimate the ice thickness along the glacier flow line of Urumqi Glacier No. 1. Comparision results of DEMs (Digital Elevation Models) from different periods showed that Urumqi Glacier No. 1 has experienced an accelerated thinning and a volume loss since the 1960s (Wang et al., 
2014b). The accelerated mass loss was also observed from the annual observation of glacier mass balance since 1959 (Liu et al., 1997; Han et al., 2006; Jing et al., 2006; Li et al., 2011; Zhang et al., 2014). In addition, borehole drilling results showed that the ice temperature has increased by $0.9^{\circ} \mathrm{C}$ (increasing rate of $0.06^{\circ} \mathrm{C} / \mathrm{a}$ ) during $1986-2001$ and by $0.4^{\circ} \mathrm{C}$ (increasing rate of $0.08^{\circ} \mathrm{C} / \mathrm{a}$ ) during 2001-2006 (Li et al., 2011), further leading to the acceleration of glacier shrinkage.

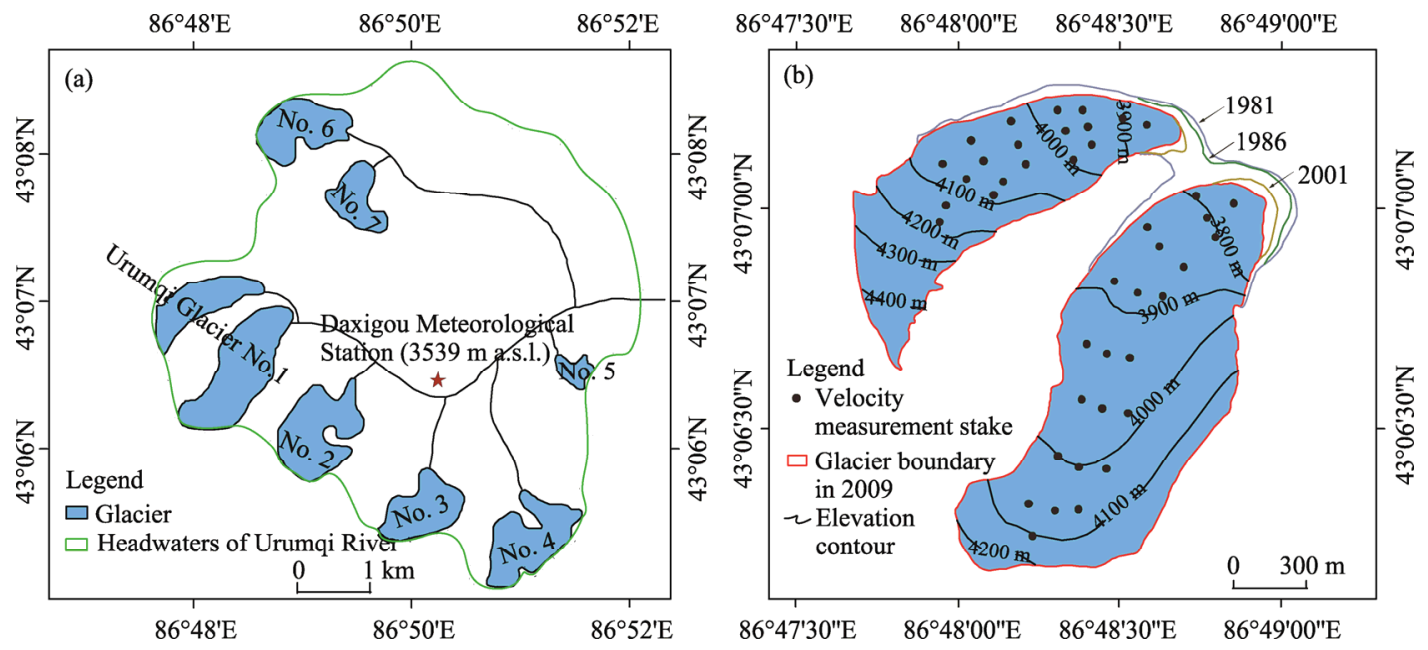

Fig. 1 (a) Overview of Urumqi Glacier No. 1 and the surrounding area at the headwaters of Urumqi River, Tianshan Mountains, Northwest China, and (b) the surface elevation contours of Urumqi Glacier No. 1 in 2009 and glacier boundaries in different years indicated by various color lines. It should be noted that a total of 7 glaciers are located at the headwaters of Urumqi River, marked by No. 1-7, respectively.

\section{Data and methods}

\subsection{Glacier flow velocity}

Glacier flow velocity was measured by surveying stakes installed in the glacier. A 42-stake network was set up across the entire glacier (Fig. 1b). These 42 stakes were evenly distributed in different elevations, covering nearly the whole glacier. It should be noted that only few stakes were distributed at the headwalls of the glacier due to inaccessible steep slopes. The velocity measurement stakes can also be used as mass balance measurement stakes. The total number of stakes varied from year to year, but it was never smaller than half of the recent number (Tianshan Glaciological Station, 2011).

As mentioned above, sporadid glacier flow velocity measurements were taken in September 1959 and also in August-September 1973 (Tianshan Glaciological Station, 2011). Since 1980, the flow velocity of Urumqi Glacier No. 1 was continuously surveyed in late August or early September every year. The measurements in different years were performed via various survey methods. Specifically, measurements of glacier flow velocity in 1959, 1973 and 1980-2001 were accomplished via repeated theodolite measurements from observation stations on the bedrock ridge near the northern edge of the glacier terminus. During 2002-2006, glacier flow velocity was measured using the total station. Since 2007, the RTK-GPS, a widely-used method for velocity measurements in recent years (Sunil et al., 2007; Rajner, 2010; Yang et al., 2014), was introduced to survey flow velocity. Our survey was undertaken using a Unistrong E650 GPS. Receivers were placed at a fixed base position that was the same as the previous year, and roving receivers were used to concurrently survey the stakes. The repeat measurements can be used to construct a flow velocity field. A RTK differential mode was simultaneously adopted, which resulted in a survey error of $\sim 0.10-0.30 \mathrm{~m}$ for the geodetic-quality GPS receivers (Rivera et al., 2005).

Furthermore, other various errors may also be introduced in the measurements of glacier flow velocity. First, some stakes fell down or moved from their original positions due to the complicated morphology, rapid glacier flow velocity, or severe glacier melting. Therefore, those 
stakes need to be reinstalled to the original positions. However, sometimes the needed reinstallation is impossible under difficult situations (e.g., movement into crevassed areas or glacier surface streams). Second, the measurement duration must be sufficient to assure the survey accuracy, otherwise, errors may occur. For example, the GPS measurement for each stake requires at least $5 \mathrm{~min}$.

Glacier flow velocity was obtained by calculating the displacement of the stakes per unit time. The coordinate system was independent. The displacement of a stake was determined by taking the difference between each component of the coordinate. Then by dividing the displacement by the unit time, the glacier flow velocity in each direction per unit time was acquired. The magnitude of glacier flow velocity $\left(U_{x y}\right.$, in unit of $\left.\mathrm{m} / \mathrm{a}\right)$ and the direction of glacier flow velocity $\left(\alpha\right.$, in unit of $\left.{ }^{\circ}\right)$ were determined using the following equations:

$$
\begin{aligned}
& U_{x y}=\sqrt{U_{x}{ }^{2}+U_{y}{ }^{2}}, \\
& \alpha=90-\arctan \frac{U_{y}}{U_{x}},
\end{aligned}
$$

where $U_{x}$ and $U_{y}$ are the flow velocity components parallel to the $x$ and $y$ axes (m/a), respectively; and $\alpha$ is the direction of glacier flow velocity $\left({ }^{\circ}\right)$, which is the degree relative to north. Generally, the accuracy of $U_{x y}$ is less than $10 \%$ of the error in the input data and the accuracy of $\alpha$ is no more than $\pm 2^{\circ}$ (Tianshan Glaciological Station, 2011).

To examine the variations in flow velocity of Urumqi Glacier No. 1 from 1981 to 2011, we analyzed the spatial distributions of glacier flow velocity in 1980/1981, 1990/1991, 2000/2001, and 2010/2011 and the changes of glacier flow velocity with the time interval of 10 years. In addition, we chose the topographic maps containing Urumqi Glacier No. 1 made in 1981 (1:5000; aerial photograph), 1986 (1:5000; stereophotogrammetric survey), 2001 (1:5000; theodolite), and 2009 (1:5000; RTK-GPS) to determine the glacier boundary in these years. More details about these topographic maps can be found in Wang et al. (2014a).

\subsection{Factor analyses}

Glacier flow velocity may be influenced by climatic condition, glacial morphology, glacial mass balance, subglacial topography, subglacial water pressure, and internal stress (McSaveney and Gage, 1968; Iken and Truffer, 1997; Herman et al., 2011; Nishimura et al., 2013; Sugiyama et al., 2013). In this study, the correlation coefficients between various variables were determined by statistical analysis in the software Microsoft Office Excel. The $P$-value was used to test the statistical significance and the difference was considered to be significant at $P<0.05$ level. Furthermore, we adopted the path coefficient analysis to determine the direct and indirect influences of causal variables on glacier flow velocity. Developed by Wright (1921), the path coefficient analysis is a method that quantifies the contribution of causal variables to a targeted influence variable. This method was originally used in the context of genetics (Dewey and Lu, 1959). It has since been widely applied to many other fields (e.g., Board et al., 1997; Machikowa and Laosuwan, 2011; Akintunde, 2012). The method can be expressed using the following formula by assuming independent variables $x_{1}, x_{2}, x_{3}, \ldots, x_{n}$ and dependent variable $y$ (Jing et al., 2011):

$$
\left\{\begin{array}{c}
p_{y x_{1}}+r_{x_{1} x_{2}} p_{y x_{2}}+\cdots+r_{x_{1} x_{n}} p_{y x_{n}}=r_{x_{1} y} \\
r_{x_{2} x_{1}} p_{y x_{1}}+p_{y x_{2}}+\cdots+r_{x_{2} x_{n}} p_{y x_{n}}=r_{x_{2} y} \\
\vdots \\
r_{x_{n} x_{1}} p_{y x_{2}}+r_{x_{n} x_{2}} p_{y x_{2}}+\cdots+p_{y x_{n}}=r_{x_{n} y}
\end{array}\right.
$$

where, $r_{x_{i} x_{j}}$ is the correlation coefficient between $x_{i}$ and $x_{j} ; r_{x_{i} y}$ is the correlation coefficient between $x_{i}$ and $y ; p_{y x_{i}}$ is the direct path coefficient of $x_{i}$ and $y$; and $r_{x_{i} x_{j}} p_{y x_{i}}$ is the indirect path coefficient of $x_{i}$ and $y$ via $x_{j}$. 
The direct path coefficient $\left(p_{y x_{i}}\right)$ can be expressed as Equation 4:

$$
p_{y x_{i}}=b_{i} \delta_{x_{i}} / \delta_{y}(i=1,2,3, \ldots, n),
$$

where, $b_{i}$ is the partial regression coefficient of $y$ and $x_{i}$; and $\delta_{x_{i}}$ and $\delta_{y}$ are the standard deviations of $x_{i}$ and $y$, respectively. The path coefficient of residual terms can be expressed as Equation 5 and the large value indicates the deviation is relatively large or some important factors are not considered.

$$
p_{y x_{e}}=\sqrt{1-\left(r_{x_{1} y} p_{y x_{1}}+r_{x_{2} y} p_{y x_{2}}+\cdots+r_{x_{n} y} p_{y x_{n}}\right)} \text {. }
$$

In our study, glacier flow velocity was chosen as the dependent variable, while glacier area, glacier length, glacier mass balance, ice thickness, air temperature and precipitation were selected as the independent variables. The data of glacier area and length have been published in our previous study (Wang et al., 2014a). It should be noted that ice thickness of Urumqi Glacier No. 1 was measured in 1981, 2001, and 2006 (Wang et al., 2014b), and the ice thickness used for other years $(1981,1986,1992,1994,2000,2001,2006$, and 2009) was calculated by the empirical formula for uniformity (Liu et al., 2003). Glacier mass balance was observed by the stake/snow pit method since 1959. Air temperature and precipitation data were obtained from the Daxigou Meteorological Station $\left(43^{\circ} 06^{\prime} \mathrm{N}, 86^{\circ} 50^{\prime} \mathrm{E}\right.$; $3539 \mathrm{~m}$ a.s.1.), which is $3 \mathrm{~km}$ southeast of Urumqi Glacier No. 1. A continuous time series of air temperature and precipitation data are available from the station, which has been operated by the Xinjiang Uygur Autonomous Region Meteorological Bureau.

\section{Results and discussion}

\subsection{Spatial and temporal distribution of glacier flow velocity}

Glacier flow velocity values in 1980/1981, 1990/1991, 2000/2001, and 2010/2011 are shown in Figure 2. For the years 1980/1981, 1990/1991, 2000/2001, and 2010/2011, the values of average glacier flow velocity were $5.5,4.6,3.8$, and $3.3 \mathrm{~m} / \mathrm{a}$, respectively; and the values of maximum glacier flow velocity were 10.6, 8.3, 6.1, and $4.6 \mathrm{~m} / \mathrm{a}$, respectively (Fig. 2a). The decreasing rate of average glacier flow velocity was $0.07 \mathrm{~m} / \mathrm{a}$ from 1980/1981 to 2010/2011. Spatially, the flow velocity tended to decrease in the upper and lower parts of the glacier. Glacier flow velocity was largest near the main flow line and smallest near the margin. The bedrock of Urumqi Glacier No. 1 shows a U-shaped pattern and is quite regular with altitudes decreasing towards the ice front (Wang et al., 2014b). The directions of glacier flow velocity in different years were all parallel with the valley direction. Generally, annual variations in the directions of glacier flow velocity were small, less than $1^{\circ}-3^{\circ}$.

Variations of glacier flow velocity for the western and eastern branches showed a consistent pattern from 1980/1981 to 2010/2011 (Figs. 2b and c). The average glacier flow velocity of the western branch was 1.4 times higher than that of the eastern branch. This may be due to the larger thickness and the steeper slope of the western branch (Wang et al., 2014b). The slope of the western branch is on average $8^{\circ}$ higher than that of the eastern branch. The steeper slope can induce the ice to transfer from the accumulation zone to the ablation zone at a higher velocity. Assuming that ice deforms in simple shear fashion, glacier flow velocity $\left(u_{s}\right)$ can be given by the following equation (Cuffey and Paterson, 2010):

$$
u_{s}=u_{b}+\frac{2 A}{n+1}(\rho g H \sin \alpha)^{n} H,
$$

where $u_{s}$ is the glacier flow velocity $(\mathrm{m} / \mathrm{a}) ; u_{b}$ is the basal velocity $(\mathrm{m} / \mathrm{a}) ; \rho$ is the ice density $(\mathrm{m} / \mathrm{a})$; $g$ is the gravitational acceleration $\left(\mathrm{m} / \mathrm{s}^{2}\right) ; H$ is the ice thickness $(\mathrm{m}) ; \alpha$ is the down-glacier surface slope $\left({ }^{\circ}\right)$; and $A$ is the rate factor and $n$ is the exponent, both of them are parameters in Glen's flow law. The second term of Equation 6 is proportional to $H^{4}$ and $(\sin \alpha)^{3}$, which states that the glacier flow velocity is highly dependent on the ice thickness and surface slope. 

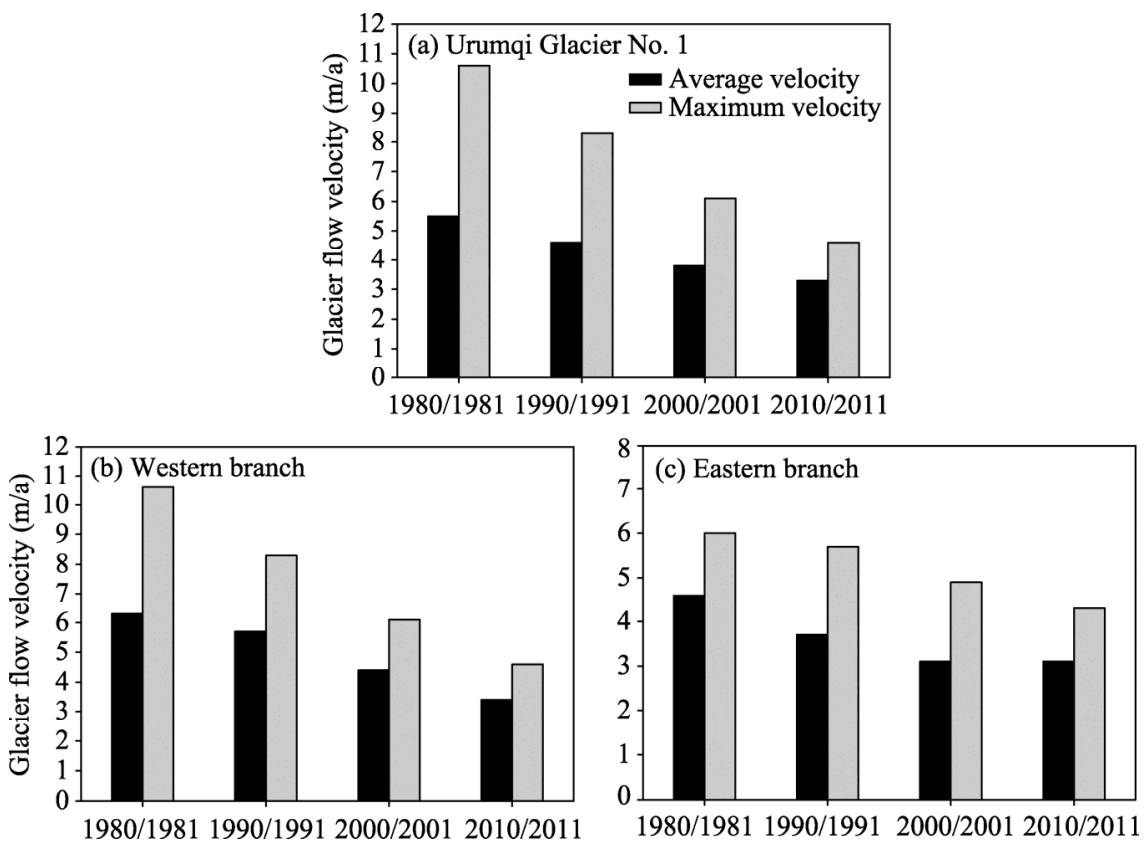

Fig. 2 Average and maximum flow velocities of the entire Urumqi Glacier No. 1 (a), the western branch (b), and the eastern branch (c) from 1980/1981 to 2010/2011

Based on the ice thickness results of Urumqi Glacier No. 1 from ground penetrating radar survey (Wang et al., 2014b), we determined that locations with the maximum glacier flow velocity for the two branches were at the places where ice is the thickest (Fig. 3). The locations with the maximum glacier flow velocity for both branches moved backward (i.e., towards upstream) from 1980/1981 to 2010/2011. This is likely because the glacier thinned more in the lower part than in the upper part, resulting in a decrease of glacier flow velocity in the lower part.

Urumqi Glacier No. 1 also showed seasonal variations in flow velocity (Zhou et al., 2009). Monthly observations of glacier flow velocity from 2006 to 2008 indicated that glacier flow velocity in summers was higher than that in winters. This may be due to the fact that the resulted melting water from high temperature in summers may have lubricated the ice-bed and speeded up the glacier flow.

Compared with other glaciers in China, the flow velocity of Urumqi Glacier No. 1 is lower because of the smaller size. For examples, the average flow velocity of Qiyi Glacier in the central Qilian Mountains was $9.02 \mathrm{~m} / \mathrm{a}$ from 1958 to 2007 (Jing et al., 2011). The maximum flow velocity reached up to $32.6 \mathrm{~m} / \mathrm{a}$ in the western branch and $32.4 \mathrm{~m} / \mathrm{a}$ in the eastern branch in Laohugou Glacier No. $12\left(39^{\circ} 26^{\prime} \mathrm{N}, 96^{\circ} 32^{\prime} \mathrm{E}\right)$ in the western Qilian Mountains (Liu et al., 2010). In contrast, the maximum flow velocity of Yanglonghe Glacier No. $5\left(39^{\circ} 13^{\prime} \mathrm{N}, 98^{\circ} 33^{\prime} \mathrm{E}\right)$ in the central Qilian Mountains was $8.8 \mathrm{~m} / \mathrm{a}$, and the maximum flow velocity of Chongce Ice Cap $\left(35^{\circ} 14^{\prime} \mathrm{N}, 81^{\circ} 07^{\prime} \mathrm{E}\right)$ in the western Kunlun Mountains was $4.16 \mathrm{~m} / \mathrm{a}$. The maximum velocity of Puruogangri Ice Field $\left(33^{\circ} 44^{\prime}-34^{\circ} 04^{\prime} \mathrm{N}, 89^{\circ} 20^{\prime}-89^{\circ} 50^{\prime} \mathrm{E}\right)$, the largest ice field in the northern Tibetan Plateau, was $3.67 \mathrm{~m} / \mathrm{a}$ in 2000 (Jing et al., 2003). The thinning of Urumqi Glacier No. 1 was remarkable during the period of 1962-2009 (Wang et al., 2014a), resulting in the decreasing of glacier flow velocity. During the period of 1959-2010, the cumulative glacier mass balance of Urumqi Glacier No. 1 was $-14,883 \mathrm{~mm}$ water equivalent. And the equilibrium line altitude showed a significant ascending trend with a value of approximately $90 \mathrm{~m}$ lowering (Zhang et al., 2014).

\subsection{Factor analysis}

Glacier flow velocity is mainly influenced by glacier slope, ice temperature, and ice thickness (Hodge, 1974; Mair et al., 2001). Generally speaking, glacier slope represents the morphological 
$86^{\circ} 47^{\prime} 30^{\prime \prime} \mathrm{E} \quad 86^{\circ} 48^{\prime} 00^{\prime \prime} \mathrm{E} \quad 86^{\circ} 48^{\prime} 30^{\prime \prime} \mathrm{E} \quad 86^{\circ} 49^{\prime} 00^{\prime \prime} \mathrm{E}$

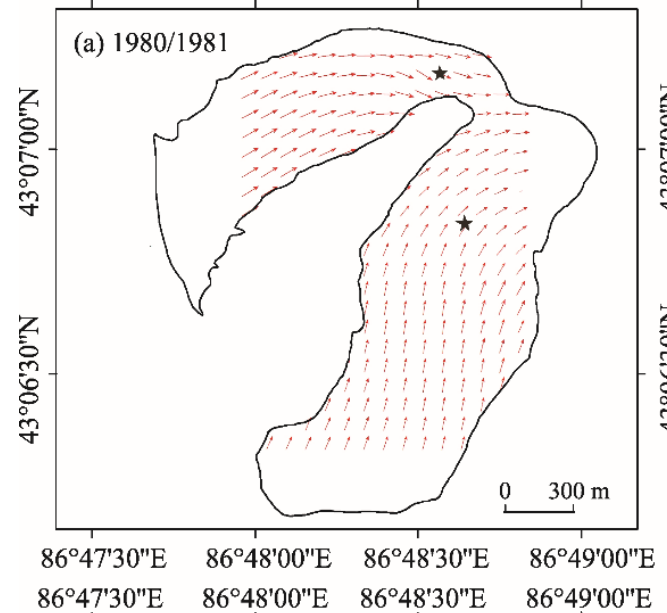

$86^{\circ} 47^{\prime} 30^{\prime \prime} \mathrm{E} \quad 86^{\circ} 48^{\prime} 00^{\prime \prime} \mathrm{E} \quad 86^{\circ} 48^{\prime} 30^{\prime \prime} \mathrm{E} \quad 86^{\circ} 49^{\prime} 00^{\prime \prime} \mathrm{E}$

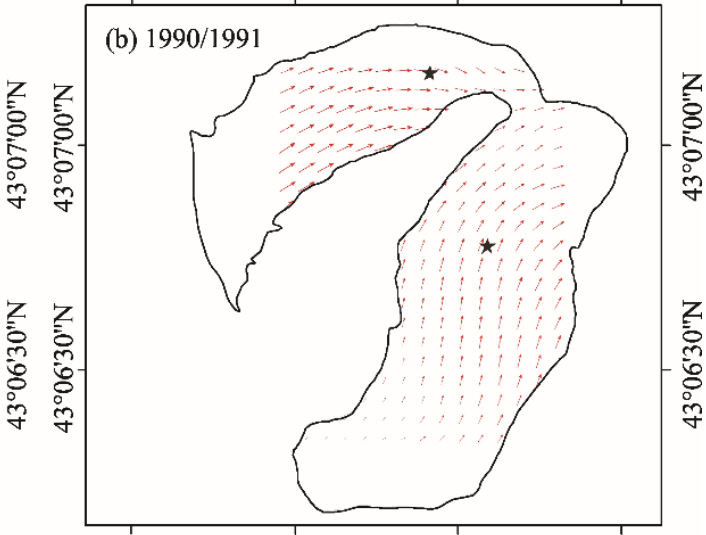

$86^{\circ} 47^{\prime} 30^{\prime \prime} \mathrm{E} \quad 86^{\circ} 48^{\prime} 00^{\prime \prime} \mathrm{E} \quad 86^{\circ} 48^{\prime} 30^{\prime \prime} \mathrm{E} \quad 86^{\circ} 49^{\prime} 00^{\prime \prime} \mathrm{E}$ $86^{\circ} 47^{\prime} 30^{\prime \prime} \mathrm{E} \quad 86^{\circ} 48^{\prime} 00^{\prime \prime} \mathrm{E} \quad 86^{\circ} 48^{\prime} 30^{\prime \prime} \mathrm{E} \quad 86^{\circ} 49^{\prime} 00^{\prime \prime} \mathrm{E}$

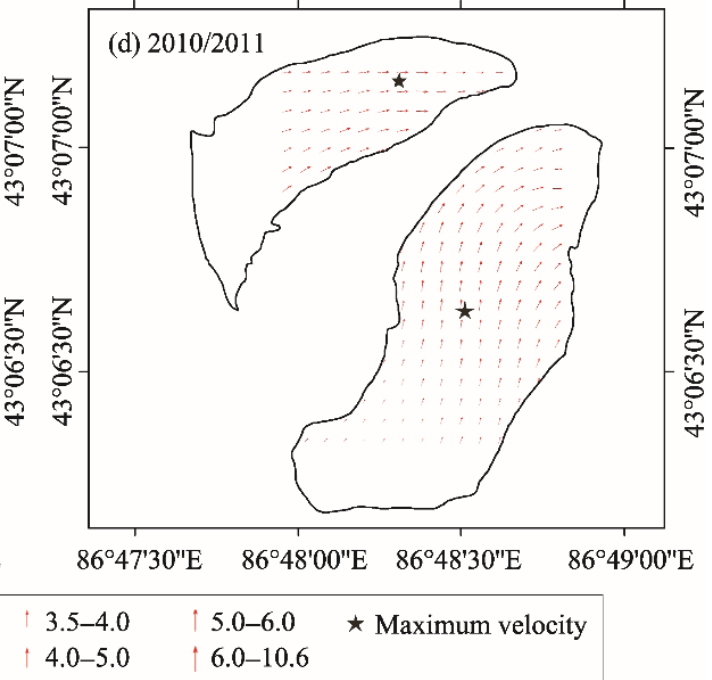

Fig. 3 Glacier flow velocity vectors in (a) 1980/1981, (b) 1990/1991, (c) 2000/2001, and (d) 2010/2011. The glacier boundaries were determined using the topographic maps in 1981, 1986, 2001 and 2009, with the survey methods of aerial photograph, stereophotogrammetric survey, theodolite, and RTK-GPS, respectively.

characteristics of glacier. Ice temperature is affected by air temperature to some extent. Moreover, ice thickness change is normally reflected by glacier mass balance and closely related to climate factors (air temperature and precipitation). Therefore, we analyzed the influences of glacier area, glacier length, glacier mass balance, ice thickness, air temperature and precipitation on glacier flow velocity using the path coefficient analysis in this study.

Correlation coefficients among different variables are shown in Table 1. Glacier flow velocity was significantly correlated with glacier area $(0.89)$, glacier length $(0.92)$, glacier mass balance (0.90), ice thickness (0.89), and air temperature (0.80). Linear analyses of air temperature and precipitation data from Daxigou Meteorological Station (Fig. 4) showed that annual mean temperature increased by $0.28^{\circ} \mathrm{C} / 10 \mathrm{a}$ and annual precipitation increased by $16.93 \mathrm{~mm} / 10 \mathrm{a}$ from 1959 to 2014. The increasing tendency was particularly obvious after 1980 with the rates of $0.54^{\circ} \mathrm{C} / 10 \mathrm{a}$ for annual mean temperature and $33.36 \mathrm{~mm} / 10 \mathrm{a}$ for annual precipitation. Glacier flow velocity exhibited a significant negative correlation with air temperature $(-0.80)$ and a non-significant negative correlation with precipitation $(-0.26)$ (Table 1). It should be noted that because the ice thickness was calculated by the empirical formula, correlation coefficients between glacier flow velocity and glacier area and between glacier flow velocity and ice thickness were the same. Glacier mass balance showed a significant negative correlation with air 
temperature (correlation coefficient of -0.89), which is similar to the result (correlation coefficient of -0.69 ) reported by Zhou et al. (2010).

Table 1 Correlation coefficients between dependent and independent variables by statistical analysis

\begin{tabular}{|c|c|c|c|c|c|c|c|}
\hline & GA & GL & IT & GMB & $\mathrm{Ta}$ & Pre & GFV \\
\hline GA & 1.00 & & & & & & \\
\hline GL & $0.97^{* *}$ & 1.00 & & & & & \\
\hline IT & $0.99^{* *}$ & $0.97^{* *}$ & 1.00 & & & & \\
\hline GMB & $0.95^{* *}$ & $0.98^{* *}$ & $0.95^{* *}$ & 1.00 & & & \\
\hline $\mathrm{Ta}$ & $-0.79^{* *}$ & $-0.84^{* *}$ & $-0.79^{* *}$ & $-0.89^{* *}$ & 1.00 & & \\
\hline Pre & -0.53 & -0.48 & -0.53 & -0.40 & 0.04 & 1.00 & \\
\hline GFV & $0.89^{* *}$ & $0.92^{* *}$ & $0.89^{* *}$ & $0.90^{* *}$ & $-0.80^{* *}$ & -0.26 & 1.00 \\
\hline
\end{tabular}

Note: GA, glacier area; GL, glacier length; IT, ice thickness; GMB, glacier mass balance; Ta, air temperature; Pre, precipitation; GFV, glacier flow velocity. ${ }^{* *}$ indicates significant difference at $P<0.01$ level. Glacier area, glacier length, glacier mass balance, ice thickness, air temperature and precipitation are independent variables, while glacier flow velocity is the dependent variable.

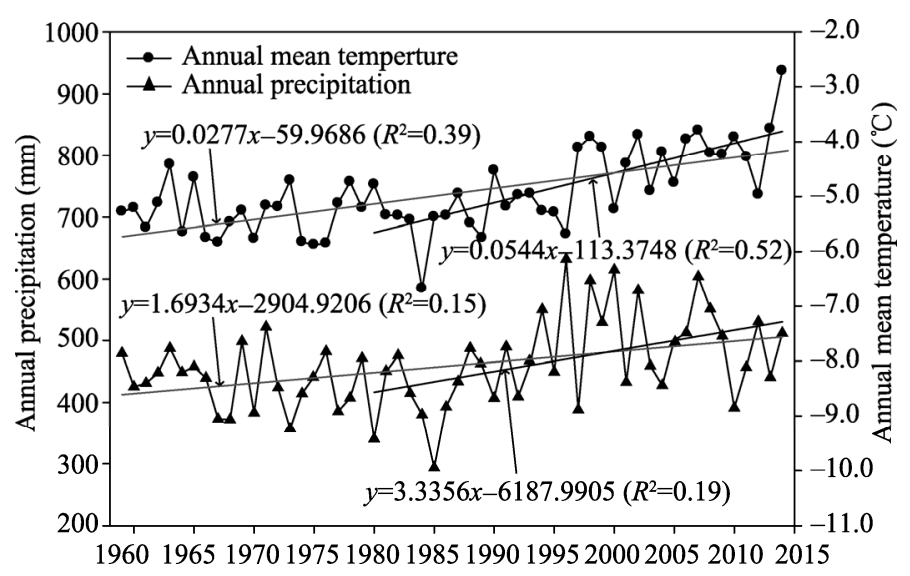

Fig. 4 Changes of annual mean temperature and annual precipitation of Daxigou Meteorological Station from 1959 to 2014

Again, glacier flow velocity was significantly correlated with all the aforementioned variables and all the variables are independent (with an exception of precipitation; see Table 1). We thus used the path coefficient analysis to determine the direct and indirect influences of these factors on glacier flow velocity. The direct and indirect path coefficients between glacier flow velocity and those independent variables (glacier morphological factors, glacier mass balance, and climate factors) are shown in Table 2. The direct path coefficients of glacier area, glacier length, glacier mass balance, ice thickness, air temperature, and precipitation with glacier flow velocity were $59.97,-1.44,3.13,-59.89,0.59$, and 0.54 , respectively. The path coefficient of residual terms was 0.02 , indicating that the main factors influencing glacier flow velocity have already been considered in this study. To sum up, the direct path coefficient of glacier morphological factors (glacier area, glacier length, and ice thickness) with glacier flow velocity was the highest, followed by glacier mass balance and climate factors (air temperature and precipitation) (Table 2), indicating that glacier morphology exerted the greater influence on glacier flow velocity than climatic conditions, being similar to the results from the Qiyi Glacier $\left(39^{\circ} 14^{\prime} 13^{\prime \prime} \mathrm{N}, 97^{\circ} 45^{\prime} 20^{\prime \prime} \mathrm{E}\right)$ in the central Qilian Mountains, northern edge of the Qinghai-Tibetan Plateau (Jing et al., 2011). It was previously reported that glacier length and area play an important role in glacier flow velocity (Jing et al., 2011). For Urumqi Glacier No. 1, glacier flow velocity decreased with the reductions in glacier area and also with the retreats in terminus position. It should be particularly noted that more complex interactions may exist among these influencing factors and a thorough analysis is needed in future studies. 
Table 2 Path coefficients between glacier flow velocity and various influencing factors

\begin{tabular}{cccccccccc}
\hline \multirow{2}{*}{ Variable } & $\begin{array}{c}\text { Correlation coefficient } \\
\text { with GFV }\end{array}$ & $\begin{array}{c}\text { Direct path } \\
\text { coefficient }\end{array}$ & GA & GL & IT & GMB & Ta & Pre & Total \\
\cline { 5 - 9 } & & & & & & Indirect path coefficient \\
GA & 0.89 & 59.97 & & -1.39 & -59.89 & 2.96 & -0.47 & -0.29 & -59.08 \\
GL & 0.92 & -1.44 & 58.10 & & -58.07 & 3.07 & -0.50 & -0.26 & 2.36 \\
IT & 0.89 & -59.89 & 59.96 & -1.39 & & 2.97 & -0.47 & -0.29 & 60.80 \\
GMB & 0.90 & 3.13 & 56.77 & -1.41 & -56.84 & & -0.52 & -0.22 & -2.22 \\
Ta & -0.80 & 0.59 & -47.31 & 1.21 & 47.46 & -2.77 & & 0.02 & -1.39 \\
Pre & -0.26 & 0.54 & -31.94 & 0.69 & 31.68 & -1.26 & 0.02 & & -0.80 \\
\hline
\end{tabular}

\section{Conclusions}

In this study, spatial distributions and long-term changes of glacier flow velocity in Urumqi Glacier No. 1, as well as the influencing factors, were analyzed. The average flow velocity in the western branch of Urumqi Glacier No. 1 was approximately 1.4 times faster than that in the eastern branch. During the study period (i.e., 1980/1981-2010/2011), the decreasing rate of average glacier flow velocity was $0.07 \mathrm{~m} / \mathrm{a}$ and the decreasing rate may be directly or indirectly associated with the glacier retreating and thinning. The annual variation in the directions of glacier flow velocity was less than $1^{\circ}-3^{\circ}$. Glacier flow velocity was primarily influenced by glacier morphology (glacier area, glacier length, and ice thickness), and the glacier mass balance and climate conditions (air temperature and precipitation) are also significant in influencing glacier flow velocity. For Urumqi Glacier No. 1, continuous field observations (e.g., flow velocity, mass balance, and terminus change) are needed in future to further our understanding of the glacier dynamics in the context of climatic warming.

\section{Acknowledgements}

This research was funded by the National Natural Science Foundation of China (41641003, 41771077), the Funds for Creative Research Groups of China (41121001) and the Youth Innovation Promotion Association of Chinese Academy of Sciences. We are grateful to the staff and workers in the Tianshan Glaciological Station for continuous data observation and collection.

\section{References}

Akintunde A N. 2012. Path analysis step by step using excel. Journal of Technical Science and Technologies, 1(1): 9-15.

Barry R G. 2006. The status of research on glaciers and global glacier recession: a review. Progress in Physical Geography, 30(3): 285-306.

Board J E, Kang M S, Harville B G. 1997. Path analyses identify indirect selection criteria for yield of late-planted soybean. Crop Science, 37(3): 879-884.

Cuffey K M, Paterson W S B. 2010. The Physics of Glaciers ( ${ }^{\text {th }}$ ed.). Burlington, MA: Butterworth-Heinemann, 285-398.

Dewey D R, Lu K H. 1959. A correlation and path coefficient analysis of components of crested wheatgrass seed production. Agronomy Journal, 51(9): 515-518.

Dyurgerov M B, Meier M F. 2000. Twentieth century climate change: Evidence from small glaciers. Proceeding of the National Academy of Sciences of the United States of America, 97(4): 1406-1411.

Haeberli W, Maisch M, Paul F. 2002. Mountain glaciers in global climate-related observation networks. World Meteorological Organization Bulletin, 51: 18-25.

Han T D, Ding Y J, Ye B S, et al. 2006. Massbalance characteristics of Ürümqi Glacier No. 1, Tien Shan, China. Annals of Glaciology, 43(1): 323-328.

Herman F, Anderson B, Leprince S. 2011. Mountain glacier velocity variation during a retreat/advance cycle quantified using sub-pixel analysis of ASTER images. Journal of Glaciology, 57(202): 197-207.

Hodge S M. 1974. Variations in the sliding of a temperate glacier. Journal of Glaciology, 13(69): 349-369.

Huang M H, Sun Z Z. 1982. Some flow characteristics of continental-type glaciers in China. Journal of Glaciology and Geocryology, 4(2): 35-45. (in Chinese) 
Hubbard B, Glasser N F. 2005. Field Techniques in Glaciology and Glacial Geomorphology: Glacier Mass Balance and Motion. Chichester: Wiley, 179-216.

Iken A, Truffer M. 1997. The relationship between subglacial water pressure and velocity of Findelengletscher, Switzerland, during its advance and retreat. Journal of Glaciology, 43(144): 328-338.

IPCC. 2013. Climate Change 2013: The Physical Science Basis. IPCC Working Group I Contribution to AR5. [2017-01-29]. http://www.climatechange2013.org/.

Jing Z F, Yao T D, Wang N L. 2003. The surface flow features of the Puruogangri Ice Field. Journal of Glaciology and Geocryology, 25(3): 288-290. (in Chinese)

Jing Z F, Jiao K Q, Yao T D, et al. 2006. Mass balance and recession of Ürümqi Glacier No. 1, Tianshan, China over the last 45 years. Annals of Glaciology, 43(1): 214-217.

Jing Z F, Liu L, Zhou Z M, et al. 2011. Analysis on the influencing factors of glacier flow velocity: a case study of Qiyi Glacier in Qilian Mountains. Journal of Glaciology and Geocryology, 33(6): 1222-1228. (in Chinese)

Kääb A. 2005. Combination of SRTM3 and repeat ASTER data for deriving alpine glacier flow velocities in the Bhutan Himalaya. Remote Sensing of Environment, 94(4): 463-474.

Khromova T E, Dyurgerov M B, Barry R G. 2003. Late-twentieth century changes in glacier extent in the Ak-shirak Range, Central Asia, determined from historical data and ASTER imagery. Geophysical Research Letters, 30(16): 1863.

Li H L, Ng F, Li Z Q, et al. 2012. An extended "perfect-plasticity" method for estimating ice thickness along the flow line of mountain glaciers. Journal of Geophysical Research, 117(F1): F01020.

Li Z Q, Li K M, Wang L. 2010. Study on recent glacier changes and their impact on water resources in Xinjiang, north western China. Quaternary Sciences, 30(1): 96-106.

Li Z Q, Li H L, Chen Y N. 2011. Mechanisms and simulation of accelerated shrinkage of continental glaciers: a case study of Urumqi Glacier No. 1 in eastern Tianshan, central Asia. Journal of Earth Science, 22(4): 423-430.

Li Z X, He Y Q, Wang P Y, et al. 2012. Changes of daily climate extremes in southwestern China during 1961-2008. Global and Planetary Change, 80-81: 255-272.

Liu C H, Xie Z C, Wang C Z. 1997. A research on the mass balance processes of Glacier No. 1 at the headwaters of the Urumqi River, Tianshan Mountains. Journal of Glaciology and Geocryology, 19(1): 17-24. (in Chinese)

Liu S Y, Sun W X, Shen Y P, et al. 2003. Glacier changes since the Little Ice Age maximum in the western Qilian Shan, northwest China, and consequences of glacier runoff for water supply. Journal of Glaciology, 49(164): 117-124.

Liu Y S, Qin X, Du W T, et al. 2010. Analysis of the movement features of the Laohugou Glacier No. 12 in the Qilian Mountains. Journal of Glaciology and Geocryology, 32(3): 475-479. (in Chinese)

Machikowa T, Laosuwan P. 2011. Path coefficient analysis for yield of early maturing soybean. Songklanakarin Journal of Science and Technology, 33(4): 365-368.

Mair D, Nienow P, Willis I, et al. 2001. Spatial patterns of glacier motion during a high-velocity event: Haut Glacier d'Arolla, Switzerland. Journal of Glaciology, 47(156): 9-20.

Manson R, Coleman R, Morgan P, et al. 2000. Ice velocities of the Lambert Glacier from static GPS observations. Earth, Planets and Space, 52: BF03352326.

McSaveney M J, Gage M. 1968. Ice flow measurements on Franz Josef Glacier, New Zealand, in 1966. New Zealand Journal of Geology and Geophysics, 11(3): 564-592.

Meier M F, Dyurgerov M B, Rick U K, et al. 2007. Glaciers dominate eustatic sea-level rise in the $21^{\text {st }}$ century. Science, 317(5841): 1064-1067.

Nishimura D, Sugiyama S, Bauder A, et al. 2013. Changes in ice-flow velocity and surface elevation from 1874 to 2006 in Rhonegletscher, Switzerland. Arctic, Antarctic, and Alpine Research, 45(4): 552-562.

Oerlemans J, Fortuin J P F. 1992. Sensitivity of glaciers and small ice caps to greenhouse warming. Science, 258(5079): $115-117$.

Oerlemans J. 2005. Extracting a climate signal from 169 glacier records. Science, 308(5722): 675-677.

Paul F, Kääb A, Maisch M, et al. 2004. Rapid disintegration of Alpine glaciers observed with satellite data. Geophysical Research Letters, 31(21): L21402.

Rajner M. 2010. Some remarks on determining short-period changes in glacier surface velocity using GPS technique-case study of Hans Glacier example. Geodesy and Cartography, 59(1): 39-48.

Rivera A, Casassa G, Bamber J, et al. 2005. Ice elevation changes of Glaciar Chico, southern Patagonia, using ASTER DEMs, aerial photographs and GPS data. Journal of Glaciology, 51(172): 105-112.

Schubert A, Faes A, Kääb A, et al. 2013. Glacier surface velocity estimation using repeat TerraSAR-X images: Wavelet-vs. correlation-based image matching ISPRS. Journal of Photogrammetry and Remote Sensing, 82: 49-62. 
Singh P, Singh V P. 2001. Snow and Glacier Hydrology. Dordrecht, Netherlands: Kluwer Academic Publishers, 448-529.

Strozzi T, Luckman A, Murray T, et al. 2002. Glacier motion estimation using SAR offset-tracking procedures. IEEE Transactions on Geoscience and Remote Sensing, 40(11): 2384-2391.

Sugiyama S, Fukui K, Fujita K, et al. 2013. Changes in ice thickness and flow velocity of Yala Glacier, Langtang Himal, Nepal, from 1982 to 2009. Annals of Glaciology, 54(64): 157-162.

Sunil P S, Reddy C D, Ponraj M, et al. 2007. GPS determination of the velocity and strain-rate fields on Schirmacher Glacier, central Dronning Maud Land, Antarctica. Journal of Glaciology, 53(183): 558-564.

Tianshan Glaciological Station. 2011. The Annual Report. Lanzhou: Cold and Arid Regions Environmental and Engineering Research Institute, Chinese Academy of Sciences, Vol. 1-20.

Wang P Y, Li Z Q, Wang W B, et al. 2013. Changes of six selected glaciers in the Tomor region, Tian Shan, Central Asia, over the past $\sim 50$ years, using high-resolution remote sensing images and field surveying. Quaternary International, 311: $123-131$.

Wang P Y, Li Z Q, Li H L, et al. 2014a. Comparison of glaciological and geodetic mass balance at Urumqi Glacier No. 1, Tian Shan, Central Asia. Global and Planetary Change, 114: 14-22.

Wang P Y, Li Z Q, Jin S, et al. 2014b. Ice thickness, volume and subglacial topography of Urumqi Glacier No. 1, Tianshan Mountains, central Asia, by ground penetrating radar survey. Journal of Earth System Science, 123(3): 581-591.

Wright S. 1921. Correlation and causation. Journal of Agricultural Research, 20(7): 557-585.

Xu X K, Pan B L, Hu E, et al. 2011. Responses of two branches of Glacier No. 1 to climate change from 1993 to 2005, Tianshan, China. Quaternary International, 236(1-2): 143-150.

Yang Y D, Sun B, Wang Z M, et al. 2014. GPS-derived velocity and strain fields around Dome Argus, Antarctica. Journal of Glaciology, 60(222): 735-742.

Zemp M, Hoelzle M, Haeberli W. 2009. Six decades of glacier mass-balance observations: a review of the worldwide monitoring network. Annals of Glaciology, 50(50): 101-111.

Zhang G F, Li Z Q, Wang W B, et al. 2014. Rapid decrease of observed mass balance in the Urumqi Glacier No. 1, Tianshan Mountains, central Asia. Quaternary International, 349: 135-141.

Zhou Z M, Li Z Q, Li H L, et al. 2009. The flow velocity features and dynamic simulation of the Glacier No. 1 at the headwaters of Ürümqi River, Tianshan Mountains. Journal of Glaciology and Geocryology, 31(1): 55-61. (in Chinese)

Zhou Z M, Jing Z F, Zhao S H, et al. 2010. The response of glacier velocity to climate change: a case study of Urumqi Glacier No. 1. Acta Geoscientica Sinica, 31(2): 237-244. (in Chinese) 